Article

\title{
Involvement of NOS2 Activity on Human Glioma Cell Growth, Clonogenic Potential, and Neurosphere Generation
}

\author{
Paola Palumbo ${ }^{1, *(1)}$, Francesca Lombardi ${ }^{1}$, Giuseppe Siragusa ${ }^{1}$, Soheila Raysi Dehcordi ${ }^{2}$, \\ Sabino Luzzi ${ }^{2}\left(\mathbb{D}\right.$, AnnaMaria Cimini ${ }^{1,3}$, Maria Grazia Cifone ${ }^{1}$ and Benedetta Cinque ${ }^{1}$ \\ 1 Department of Life, Health \& Environmental Sciences, University of L'Aquila, Building Delta 6, Coppito, \\ 67100 L'Aquila, Italy; francesca.lombardi@univaq.it (F.L.); giuseppe.siragusa@graduate.univaq.it (G.S.); \\ annamaria.cimini@univaq.it (A.C.); mariagrazia.cifone@univaq.it (M.G.C.); \\ benedetta.cinque@univaq.it (B.C.) \\ 2 Operative Unit of Neurosurgery, San Salvatore Hospital, 67100 L'Aquila, Italy; soheila.raysi@alice.it (S.R.D.); \\ sabino.luzzi@gmail.com (S.L.) \\ 3 Sbarro Institute for Cancer Research and Molecular Medicine and Center for Biotechnology, Temple \\ University, Philadelphia, PA 19122, USA \\ * Correspondence: paola.palumbo@univaq.it; Tel.: +39-0862-433-554
}

Received: 1 August 2018; Accepted: 14 September 2018; Published: 17 September 2018

\begin{abstract}
Aberrant nitric oxide synthase 2 (NOS2) expression has been suggested as an interesting therapeutic target that is being implicated as a component of the molecular profile of several human malignant tumors, including glioblastoma, which is the most aggressive brain tumor with limited therapeutic options and poor prognosis. The aim of the present work was to evaluate the effect of $1400 \mathrm{~W}$, a specific NOS2 inhibitor, on human glioma cells in terms of clonogenic potential, proliferation, migration rate, and neurosphere generation ability. NOS2 expression was determined by Western blotting. Nitric oxide (NO) production was measured through nitrite level determination. The trypan blue exclusion test and the plate colony formation assay were performed to evaluate cell proliferation and clonogenic potential. Cell proliferation and migration ability was assessed by the in vitro wound-healing assay. Neurosphere generation in a specific stemcell medium was investigated. NOS2 was confirmed to be expressed in both the glioma cell line and a human glioma primary culture, and overexpressed in relative derived neurospheres. Experiments that aimed to evaluate the influence of 1400W on U-87 MG, T98G (glioblastoma cell lines) and primary glioma cells sustained the crucial role played by NOS2 in proliferation, colony formation, migration, and neurosphere generation, thus supporting the emerging relevance of a NOS2/NO system as a prognostic factor for glioma malignancy and recurrence.
\end{abstract}

Keywords: NOS2; human glioma cells; 1400W NOS2 inhibitor; tumor cell proliferation and migration; clonogenic potential; neurosphere generation

\section{Introduction}

Glioblastoma (GBM), the most malignant adult brain tumor, is characterized by a high proliferative and invasive rate with very limited therapeutic options and poor prognosis [1-3]. Despite multiple studies that have aimed to define the potential determinants of the aggressiveness of this tumor, the mechanisms of GBM genesis remain undefined, and the molecular factors underlying its aggressiveness are still unclear [4,5]. The current pathophysiological hypothesis involves so-called glioma stem cells (GSCs) being responsible for the formation, expansion, recurrence, and the high therapy resistance of GBM [6-10]. The ability to promote glioma relapse, angiogenesis, invasiveness, 
and therapeutic resistance renders GSCs a potential target for anti-GBM therapy [11-13]. Several studies have suggested that gliomas, similar to most established malignant tumors, are characterized by a moderately inflammatory environment. The inflammatory process seems to be involved in all of the steps of tumorigenesis, promoting the genomic instability, proliferation, and survival of malignant cells, as well as angiogenesis, resistance to therapy, local or systemic immunosuppression, and also raising the metastatic process [14-19]. Aberrant nitric oxide synthase 2 (NOS2) expression and its enzymatic product nitric oxide (NO), which play a crucial role in the pathophysiology of several inflammatory disorders, have been implicated in the development, growth and progression of several human malignant tumors, including glioma [20-22]. NOS2 has been reported highly expressed in grade III astrocytomas and glioblastomas, with a positive correlation between its expression and tumor grade [20]. As recently reviewed [23], an overexpressed NOS2/NO system in the tumor cell induces invasion, angiogenesis, immunosuppression, differentiation, and therapeutic resistance in gliomas. GSCs have been shown to express high NOS2 levels, which were correlated with a poorer glioma patient survival [24]. Furthermore, the silencing of NOS2 expression by RNA interference decreased in vitro brain glioma-initiating cells (GICs), highlighting the main role of NOS2 in GSC biology and maintenance [24]. NOS2 knockdown by RNA interference strategy or by specific inhibitors negatively affected the proliferation and invasiveness of GBM cells [20,25], and was able to reduce the progression of subcutaneous and intracranial human glioma xenografts in mice [24]. The increase or the significant inhibition of tumor cell migration were respectively recorded after treating a co-culture of U87-MG and $\mathrm{C} 6$ glioma cell lines with the NO-donor sodium nitroprusside (SNP), or the NOS inhibitor NAME

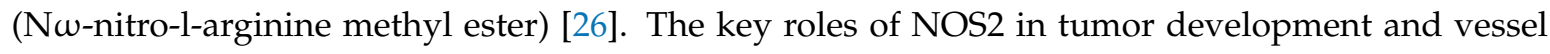
maturation in the C6 rat glioma cell line were also published [27]. In a recent study, our group reported that NOS2 expression was highly and significantly upregulated in glioma cells that were kept in the specific medium for neurosphere generation [28]. Moreover, a high and significant correlation was observed among the expression of NOS2 and SOX-2 (Sex determining region Y-box 2), which is a stemness marker that is aberrantly upregulated in both human glioma cell lines and primary cultures.

NOS2 pharmacological inhibition might therefore have potential therapeutic value in the treatment of GBM. A major class of NOS2 inhibitors are amidine derivatives, such as L-NIL, the cyclic amidine ONO-1714, and the aromatic acetamidine 1400W [29]. This latter is considered to be one of the most potent and selective NOS2 inhibitors reported to date [29-31], although it has never been approved into clinical use. Pharmacokinetic studies showed that $1400 \mathrm{~W}$ is an irreversible or an extremely slowly reversible inhibitor of NOS2, although it has been reported to be active for a few hours after administration [32,33]. In the continuous effort to develop even more selective and effective NOS2 inhibitors, different acetamidines structurally related to the $1400 \mathrm{~W}$ leading scaffold have been published [31,34-37], thus confirming the growing interest in the pharmacologic potential of NOS2 activity inhibition in different diseases, including GBM.

In the present study, the NOS2 expression and activity in the U-87 MG cell line and human GBM primary cells have been analyzed. To verify the potential functional role of NOS2 activity in glioma biology, the effects of the addition of $1400 \mathrm{~W}$ were evaluated in the proliferation and migration rate, clonogenic potential, and capacity of generating neurospheres of both GBM cell line and primary cells. To investigate the involvement of an exogenous NO on these cell systems, in some experiments, the NO chemical donor S-nitroso-N-acetylpenicillamine (SNAP) was also used.

\section{Results}

\subsection{NOS2 Expression and Activity in Adherent U-87 MG Cell Line}

To examine the effect of the well-known inhibitor of NOS2, 1400W, on the human U-87 MG cell line, the more effective concentration to inhibit NOS2 activity has been firstly evaluated by a dose-response curve. The cells were treated with different concentrations $(1 \mu \mathrm{M}, 10 \mu \mathrm{M}$, and $100 \mu \mathrm{M})$ of $1400 \mathrm{~W}$ for $24 \mathrm{~h}$, and the NOS2 enzymatic activity, which was evaluated as nitrite levels, was assayed 
in the culture medium. In Figure 1A, the results expressed as percentage versus NT are presented. The addition of a NOS2 inhibitor at $100 \mu \mathrm{M}$ significantly reduced the basal nitrite levels evaluated after $24 \mathrm{~h}(p<0.05$ vs. NT and $10 \mu \mathrm{M})$ in U-87 MG culture. Considering the high specificity of the NOS2 inhibitor $1400 \mathrm{~W}$, the amount of nitrites that reduced by $1400 \mathrm{~W}$ should be attributable to the NOS2 activity. The cell number appeared to be significantly reduced by the incubation of $100 \mu \mathrm{M} 1400 \mathrm{~W}$ for $24 \mathrm{~h}$, as analyzed by the Trypan blue dye exclusion test $(p<0.05)$. It is of note that the dead cell number was not influenced by any different concentration of $1400 \mathrm{~W}$ (Figure 1B). The analysis of the percentage of U-87 MG dead cells, as assessed through propidium iodide (PI) staining by cytofluorometry, confirmed that the $1400 \mathrm{~W}$ inhibitor did not cause a cytotoxic effect at all used concentrations (Figure 1C). A considerable decrease in the cell number and nitrite levels of 1400W was obtained with $100 \mu \mathrm{M}$; hence, the following experiments were performed with the single $1400 \mathrm{~W}$ concentration $(100 \mu \mathrm{M})$, as previously reported [24]. For these experiments, RAW 264.7 cells that were either unstimulated or stimulated with LPS and IFN- $\gamma$ were used as the negative and positive control, respectively. Also, for this cell line, no cytotoxic effect was detected when treated with 1400W for up to $100 \mu \mathrm{M}$ (data not shown).

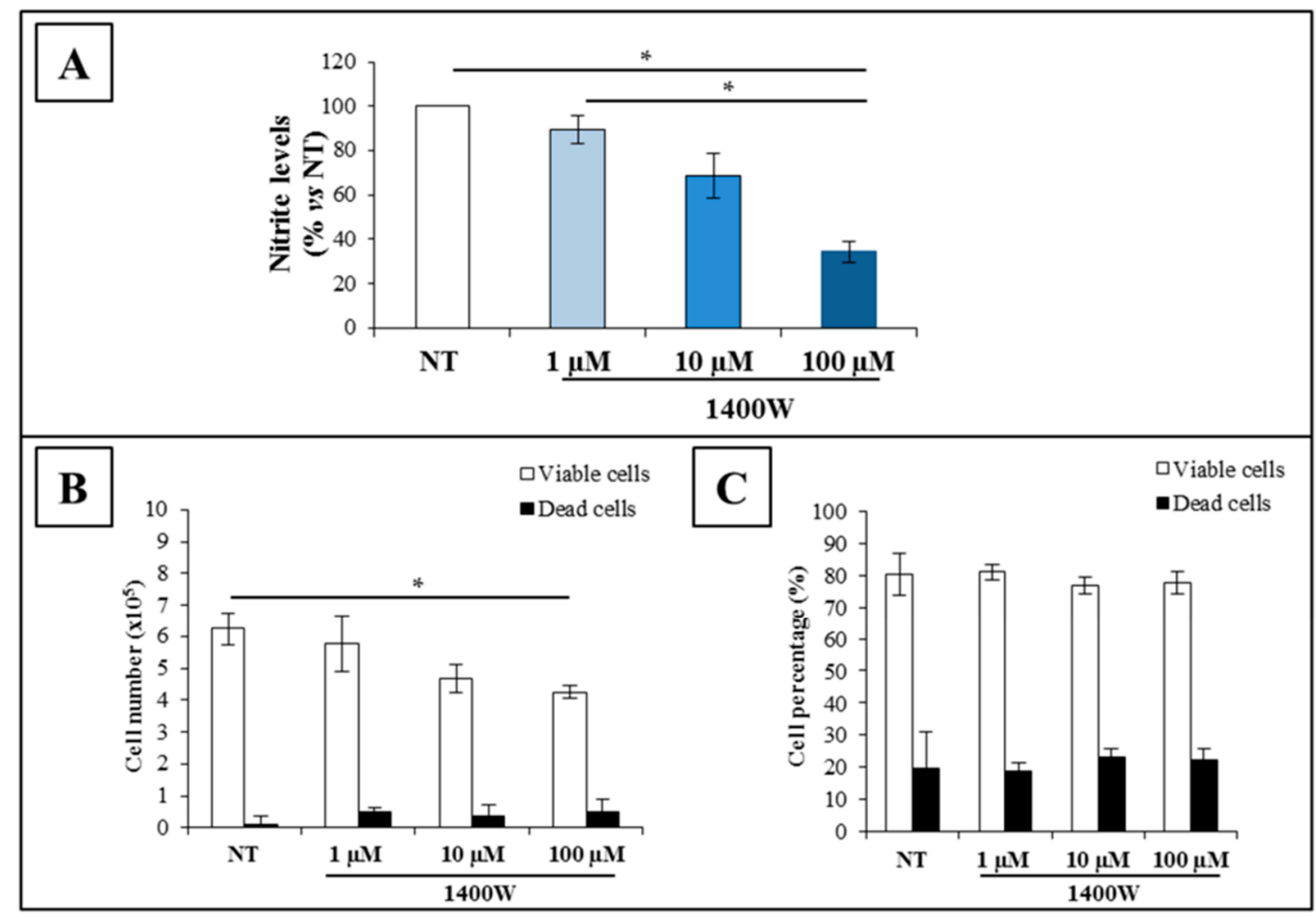

Figure 1. Effect of different concentrations of $1400 \mathrm{~W}$, a nitric oxide synthase 2 (NOS2) inhibitor, on U-87 MG human glioblastoma (GBM) cell line. (A) Nitrite levels in media from adherent U-87 MG cells cultured for $24 \mathrm{~h}$ without (not treated, NT) or with NOS2 inhibitor, $1400 \mathrm{~W}(1 \mu \mathrm{M}, 10 \mu \mathrm{M}$, and $100 \mu \mathrm{M})$. The results presented as percentage vs. NT are expressed as the mean \pm SEM from two independent experiments in triplicate. (B) U-87 MG cells were treated with $1400 \mathrm{~W}$ at $1 \mu \mathrm{M}, 10 \mu \mathrm{M}, 100 \mu \mathrm{M}$, or PBS (NT) for $24 \mathrm{~h}$, and the number of viable and dead cells was assessed by Trypan blue exclusion test and (C) by propidium iodide (PI) staining. Results are presented as the mean $\pm \mathrm{SEM}$ of two independent experiments in triplicate. For comparative analysis of groups of data, one-way ANOVA followed by Bonferroni post hoc test was used $\left({ }^{*} p<0.05\right)$.

To further confirm our previous results obtained with RT-PCR [28], NOS2 protein levels were firstly evaluated in adherent U-87 MG cells after $24 \mathrm{~h}$ of culture. As expected, U-87 MG cells basally expressed NOS2 protein, and the exposure to the $1400 \mathrm{~W}$ inhibitor did not affect the NOS2 protein 
expression, as evident in the representative Western blot shown in Figure 2A. The NOS2 protein levels expressed by fold versus those not treated (NT) are presented in Figure 2B.

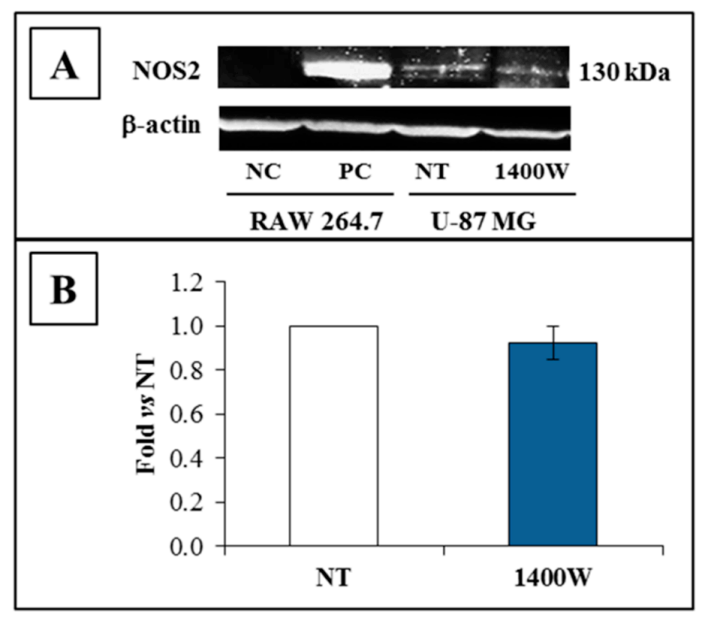

Figure 2. NOS2 protein expression of the adherent U-87 MG glioblastoma cell line. (A) Representative Western blot of NOS2 and $\beta$-actin. U-87 MG cells were cultured and treated or not with $1400 \mathrm{~W}(100 \mu \mathrm{M})$ as described for $24 \mathrm{~h}$. NC (negative control): Untreated RAW 264.7; PC (positive control): RAW 264.7 treated with LPS (Lipopolysaccharide) $(1 \mu \mathrm{g} / \mathrm{mL})$ and IFN- $\gamma$ (Interferon- $\gamma)(100 \mathrm{ng} / \mathrm{mL})$ for $24 \mathrm{~h}$. (B) Quantification analysis of blots by densitometry is expressed as fold increase vs. NT. The results from three independent experiments in duplicate are presented and expressed as mean $\pm \mathrm{SEM}$.For comparison between two means, Student's unpaired $t$-test was used.

\subsection{NOS2 Inhibition Strongly Affects the Proliferation Rate of an Adherent U-87 MG Cell Line}

The clonogenic potential of U-87 MG treated daily with $1400 \mathrm{~W}$ for 10 days was significantly lower $(p<0.0001)$ than that in the control group, which indicated the crucial role of NOS2 activity on the capacity of the glioma cell line to produce progeny. On the other hand, NO-donor SNAP $(100 \mu \mathrm{M})$ led to an improved clonogenic potential when compared to control cells ( $p<0.0001 \mathrm{vs.} \mathrm{not} \mathrm{treated} \mathrm{cells} \mathrm{and}$ 1400W-treated cells) (Figure 3B). In Figure 3A, representative microscopy images of clonogenic assay are presented, while in Figure 3B, the results expressed as the number of colonies/well (mean \pm SEM of three independent experiments performed in triplicate) are shown.

As invasiveness is one of the pathophysiological features of human GBM, to support the functional role of the NOS2/NO system in our cell system, the migration and proliferation abilities of U-87 MG cells cultured at different time intervals with or without 1400W $(100 \mu \mathrm{M})$ were also checked through an in vitro scratch wound assay. At $36 \mathrm{~h}$, a scratched monolayer of not treated U-87 MG cells was mainly closed (not shown). The effect of NO-donor SNAP $(100 \mu \mathrm{M})$ was also evaluated to verify the ability of NO to positively influence both migration and proliferation rate in our cell model. The results showed that the migration and proliferation abilities of U-87 MG cells were strongly and significantly inhibited by an NOS2 inhibitor, as evident in the representative microscopy images of the scratch-wound healing assay captured at 0 (T0), $18 \mathrm{~h}$, or $24 \mathrm{~h}$, as shown in Figure $4 \mathrm{~A}$. The results of a quantitative analysis of the wound-closure rate from two independent experiments in duplicate are reported in Figure $4 \mathrm{~B}$. Data are expressed as the \% closure rate of a scratched monolayer at $18 \mathrm{~h}$ and $24 \mathrm{~h}$ versus relative $\mathrm{T} 0$ (mean $\pm \mathrm{SEM}$ ). For the comparative evaluation of groups of data, a repeated measure two-way ANOVA followed by Bonferroni post hoc test was performed. The addition of $1400 \mathrm{~W}$ significantly and negatively affected the closure rate of a scratched U-87 MG monolayer both at $18 \mathrm{~h}(p<0.001)$ and at $24 \mathrm{~h}(p<0.0001)$. This finding could be due to the effect on cell proliferation even if a slowed cell migration could not be excluded. Accordingly with the results above described, treatment with NO-donor SNAP was able to strongly and positively influence the basal wound closure rate either at 18 hours or 24 hours ( $p<0.01$ and $p<0.001$ vs. not treated monolayers, respectively). 


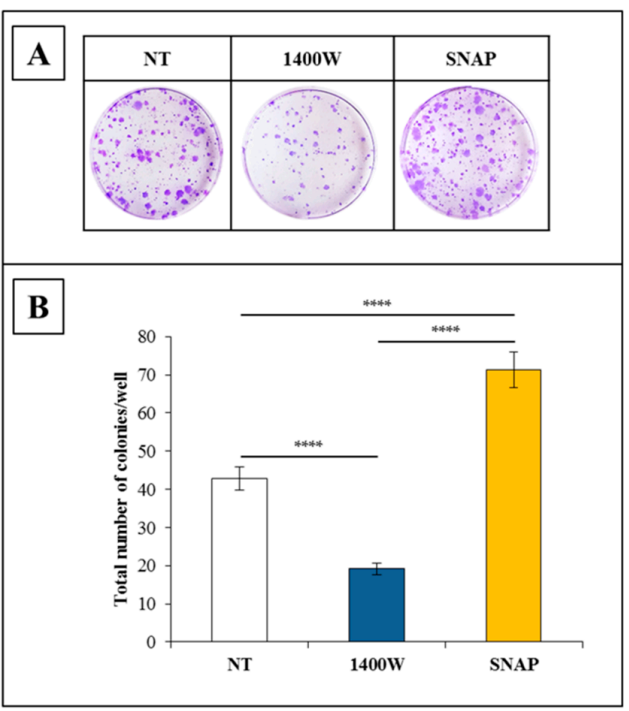

Figure 3. Nitric oxide is involved in the clonogenic potential of U-87 MG cells. (A) Representative microscopic images of clonogenic assay of U-87 MG cells after daily treatment for 10 days with NOS2 activity inhibitor 1400W (100 $\mu \mathrm{M}$ ) or nitric oxide(NO)-donor S-nitroso-N-acetylpenicillamine (SNAP) $(100 \mu \mathrm{M}) . \mathrm{NT}=$ not treated. (B) Quantitative results of clonogenic assay expressed as total number of surviving colonies/well. Viable colonies with diameter $>0.3 \mathrm{~mm}$ were counted with an ocular micrometer (mean \pm SEM of three independent experiments in triplicate). For comparative analysis of groups of data, one-way ANOVA followed by Bonferroni post hoc test was used ${ }^{* * * *} p<0.0001$ ).

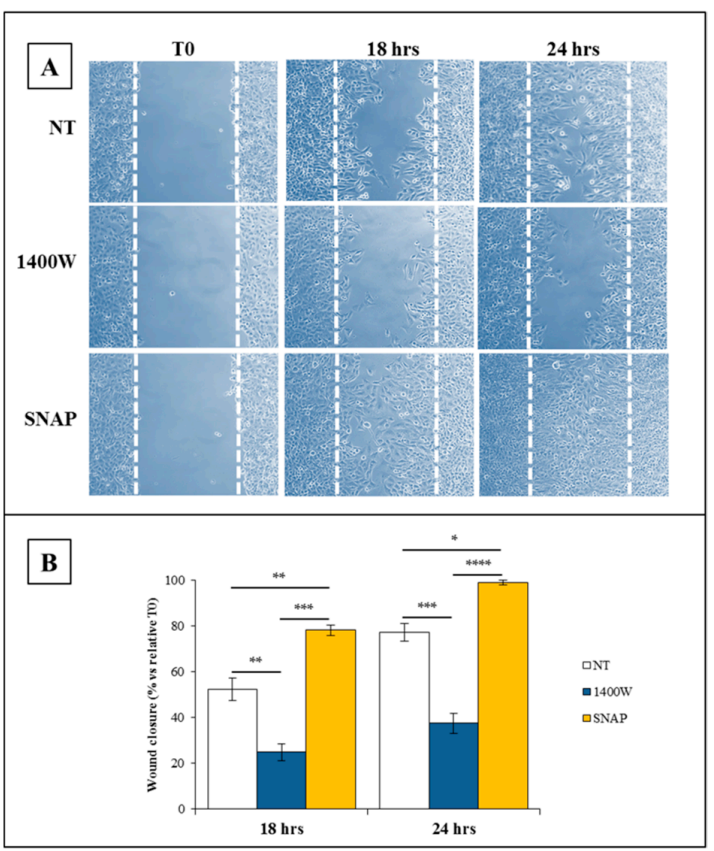

Figure 4. Involvement of NO on the scratch-wound healing ability of U-87 MG cells. (A) Representative microscopy images of the scratch-wound healing assay captured at $0 \mathrm{~h}, 18 \mathrm{~h}$, and $24 \mathrm{~h}$. Scratched U-87 MG monolayers were incubated without (not treated, NT) or with NOS2 inhibitor 1400W (100 $\mu \mathrm{M})$ or NO-donor SNAP $(100 \mu \mathrm{M})$ for the indicated times after injury $(10 \times$ magnification). (B) The extent of the wound closure rate was calculated as described and expressed as \% closure versus relative T0 at 18 $\mathrm{h}$ and $24 \mathrm{~h}$. Data are expressed as the mean \pm SEM of two independent experiments in duplicate. For a comparative analysis of groups of data, repeated measures two-way ANOVA followed by a Bonferroni post hoc test was used $\left.{ }^{*} p<0.05,{ }^{* *} p<0.01,{ }^{* * *} p<0.001,{ }^{* * *} p<0.0001\right)$. 


\subsection{NOS2 Expression and Activity in U-87 MG-Derived Neurospheres}

NOS2 expression and activity were also investigated in neurospheres. The results of Western blot analysis showed that the NOS2 protein was overexpressed in U-87 MG-generated neurospheres at 20 days of culture, thus confirming our previous results from the RT-PCR assay of NOS2 [28]. The $1400 \mathrm{~W}$ addition to the cell culture did not influence the expression levels of NOS2 when compared to neurospheres that were not treated (Figure 5A).The results that were designed to evaluate the NOS2 protein fold change versus NT are shown in Figure 5B. To investigate the involvement of NOS2 activity in the neurosphere generation, U-87 MG cells were cultured in GSC-M condition in the presence or absence of $1400 \mathrm{~W}(100 \mu \mathrm{M})$. As shown in Figure 5C, a strong increase of NOS activity was evaluated as nitrite levels occurred at 20 days when compared to basal levels at T0 $(p<0.01)$. On the other hand, nitrite levels were drastically reduced by the presence of $1400 \mathrm{~W}$ ( $p<0.01$ as compared to NT at 20 days), and were not significantly different versus NT at T0. As observed in U-87 MG cells cultured in standard medium (St-M), NOS2 inhibitor was also able to inhibit the cell growth of neurosphere-forming cells in GSC-M, ( $p<0.05$ versus not treated neurospheres) without affecting cell viability, which registered $>95 \%$ (Figure 5D).

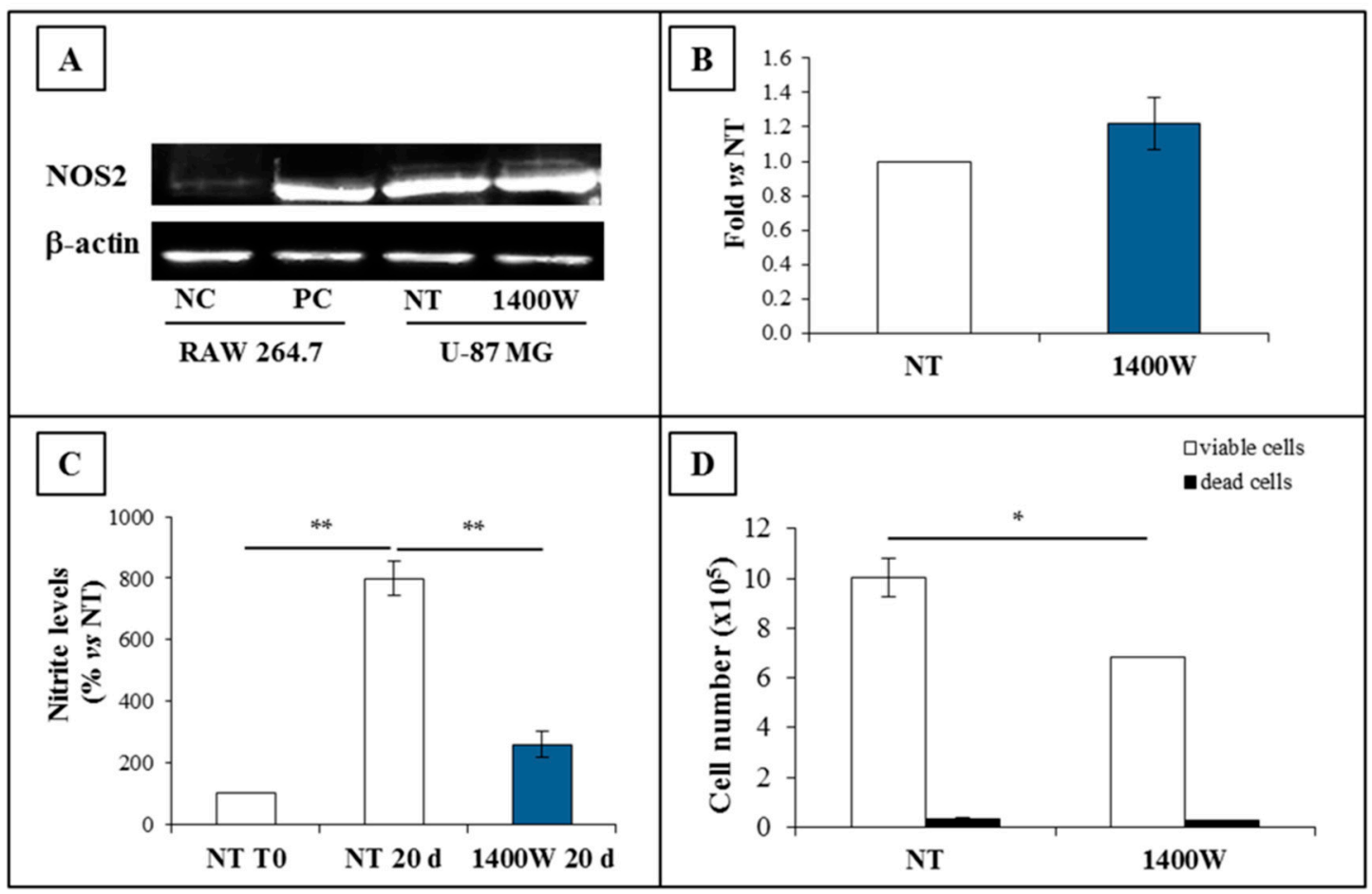

Figure 5. NOS2 protein expression and activity in U-87 MG-generated neurospheres. (A) Representative Western blot of NOS2 and $\beta$-actin. U-87 MG neurospheres were incubated in the absence (not treated, $\mathrm{NT}$ ) or presence of $1400 \mathrm{~W}(100 \mu \mathrm{M})$ daily added for 20 days. NC (negative control): untreated RAW 264.7; PC (positive control): RAW 264.7 treated for $24 \mathrm{~h}$ with LPS $(1 \mu \mathrm{g} / \mathrm{mL})$ and IFN- $\gamma(100 \mathrm{ng} / \mathrm{mL})$. (B) Quantification analysis of blots by densitometry expressed as fold vs. NT. The results from three independent experiments in duplicate are presented and expressed as mean \pm SEM. (C) Nitrite levels in U-87 MG neurospheres' media in the absence or presence of NOS2 inhibitor, with 1400W (100 $\mu \mathrm{M})$ daily added for 20 days. The nitrite levels at T0 are also shown. Data are expressed as percentage of nitrite levels vs. NT (mean \pm SEM of two independent experiments in duplicate). For comparative analysis of groups of data, a two-way analysis of variance (ANOVA) with post hoc Bonferroni test was used (** $p<0.01)$. (D) Effect of NOS2 inhibitor 1400W $(100 \mu \mathrm{M})$ on U-87 MG-generated neurosphere viability after 20-day culture. Data are expressed as the mean \pm SEM of two independent experiments performed in duplicate. For comparison between two means, Student's unpaired $t$-test was used $\left.{ }^{*} p<0.05\right)$. 


\subsection{NOS2 Inhibition Strongly Affects the Ability of U-87 MG Cells to Generate Neurosphere}

The ability of U-87 MG cells to generate neurospheres, which is a surrogate marker of GSC self-renewal, was also significantly affected by the presence of $1400 \mathrm{~W}$ at 20 days of incubation, thus supporting the functional role of the NOS2/NO system in the sphere-forming ability of tumor stem cells. Representative images captured with the phase contrast microscope are shown in Figure 6A. The data of neurosphere mean area expressed as fold versus NT are shown in Figure $5 \mathrm{~B}$ as mean \pm SEM $(p<0.05)$.

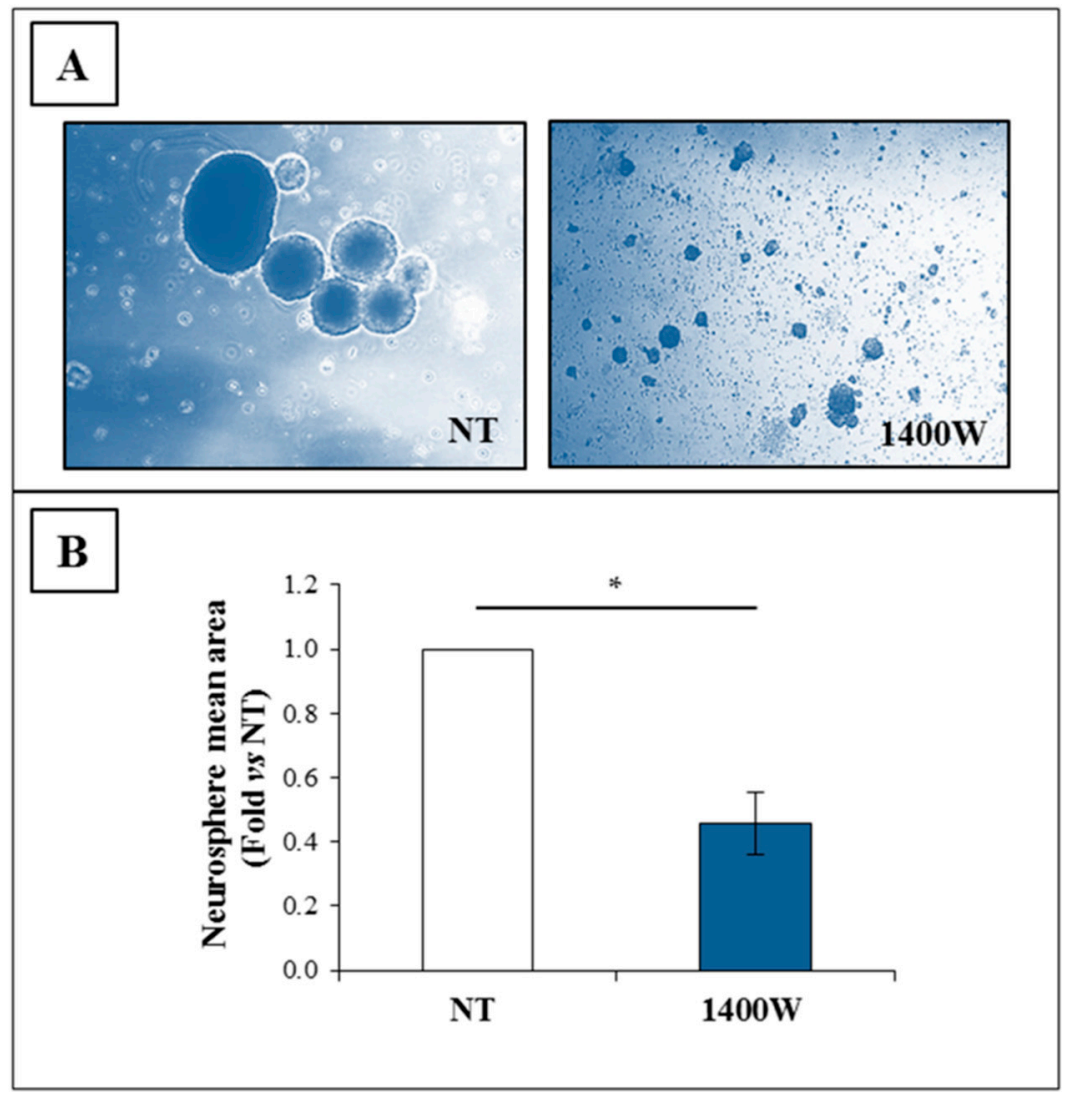

Figure 6. Nitric oxide synthase (NOS) activity inhibition strongly affects U-87 MG neurosphere generation. (A) Representative phase contrast images ( $4 \times$ magnification) of human U-87 MG cell line maintained in glioma stem cells condition (GSC-M) to allow neurospheres' generation in the absence (not treated, NT) or presence of NOS2 activity inhibitor 1400W $(100 \mu \mathrm{M})$, added daily for 20 days. Baseline condition (NT) at five-day culture is shown. (B) Quantification analysis of neurosphere mean area expressed as fold vs. NT. Data represent mean \pm SEM of two independent experiments in duplicate. For comparison between two means, Student's unpaired $t$-test was used $\left({ }^{*} p<0.05\right)$.

\subsection{Effect of $1400 W$ Inhibition on T98G Cell Line and Respective Neurospheres}

To verify the sensitivity to $1400 \mathrm{~W}$, another GBM cell line, T98G, was also exposed to NOS2 inhibitor $1400 \mathrm{~W}$ at $100 \mu \mathrm{M}$ for $24 \mathrm{~h}$. Obtained results were consistent with data from U-87 MG experiments. Figures 7 and 8 show the effect of $1400 \mathrm{~W}$ on adherent T98G and derived neurospheres, respectively. Similar to U-87 MG, treatment with 1400W did not induce a decrease of NOS2 protein levels both in adherent cells and neurospheres (Figures 7A and 8A, respectively), while it was able to negatively affect the viable cell number not showing cytotoxic effect (Figures 7B and $8 \mathrm{~B}$, respectively). Moreover, the clonogenic potential of adherent T98G, as well as the wound closure rate, were also significantly affected by $1400 \mathrm{~W}$ exposure (Figure 7C,D, respectively). The mean area of T98G-derived neurospheres daily treated with $1400 \mathrm{~W}$ and detected after 20 days was significantly reduced (Figure 8 C). 

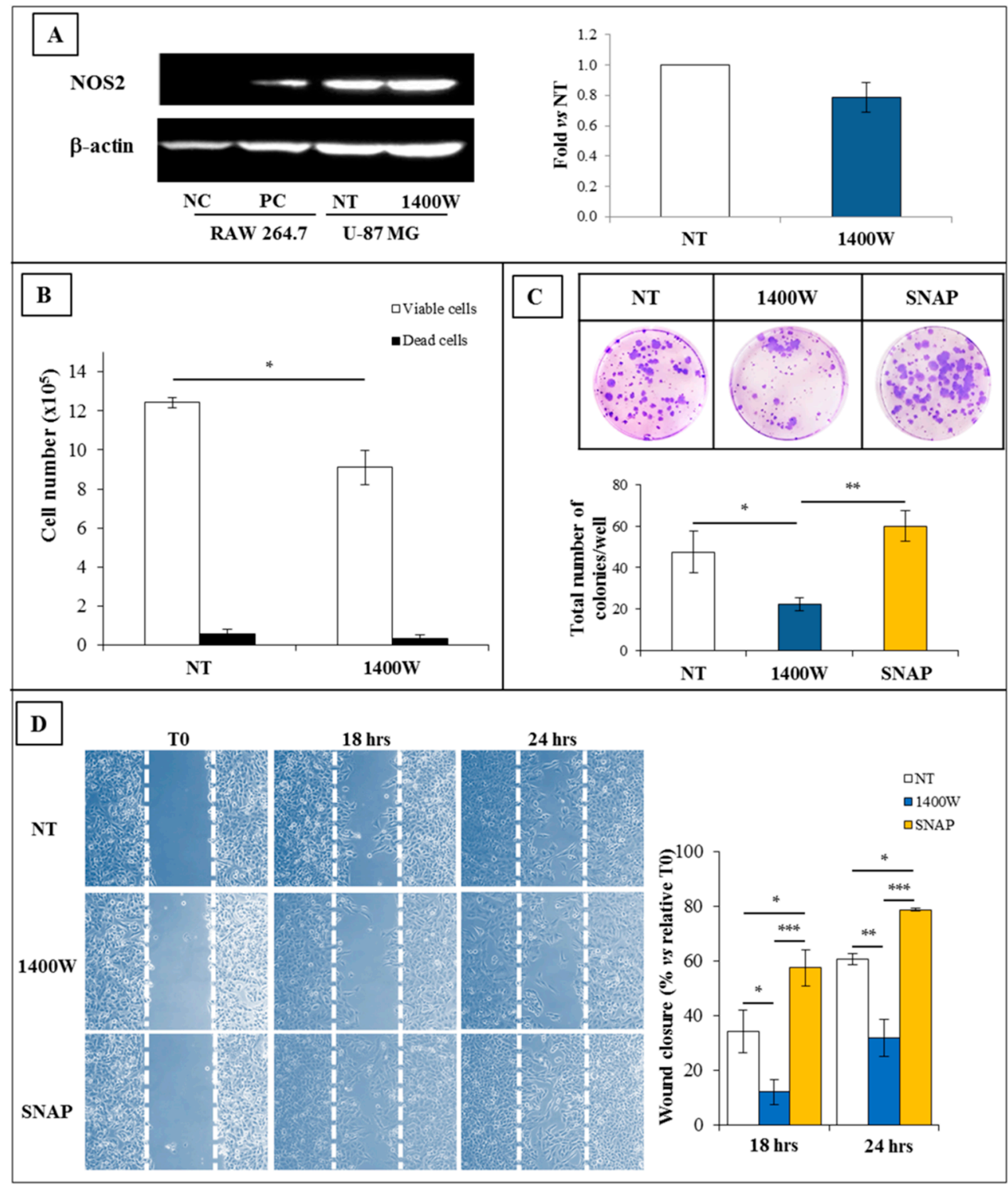

Figure 7. Expression and functional role of NOS2 in adherent human T98G cell line. (A) Representative Western blot of NOS2 and $\beta$-actin in T98G cells cultured in standard medium, (St-M) for $24 \mathrm{~h}$. NC (negative control): Untreated RAW 264.7; PC (positive control): RAW 264.7 treated with LPS $(1 \mu \mathrm{g} / \mathrm{mL})$ and IFN- $\gamma(100 \mathrm{ng} / \mathrm{mL})$ for $24 \mathrm{~h}$. Results of quantification analysis of blots by densitometry expressed as fold vs. NT are reported in the histogram. The results from one experiment in duplicate are presented as mean \pm SD. (B) Effect of NOS2 inhibitor 1400W $(100 \mu \mathrm{M})$ on T98G cell number (viable and dead cells) after $24 \mathrm{~h}$ of culture. The results from one experiment in duplicate are showed as mean \pm SD. For comparison between two means, Student's unpaired $t$-test was used $\left({ }^{*} p<0.05\right)$. (C) Representative microscopic images of clonogenic assay of T98G cells not treated (NT) or treated daily with NOS2 activity inhibitor $1400 \mathrm{~W}(100 \mu \mathrm{M})$ for 10 days. The quantitative results of clonogenic assay are reported in the histogram and expressed as the total number of surviving colonies/well. Data represent the mean \pm SD of one experiment in duplicate. For comparative analysis of groups of data, repeated two-way ANOVA measures followed by a Bonferroni post hoc test were used $(* p<0.05$, ** $p<0.01$ ). (D) Representative microscopy images of the scratch-wound healing assay captured at $0,18 \mathrm{~h}$, and $24 \mathrm{~h}$. Scratched T98G monolayers were incubated without (NT) or with NOS2 inhibitor 1400W $(100 \mu \mathrm{M})$ or NO-donor SNAP $(100 \mu \mathrm{M})$ for the indicated times after injury $(10 \times$ magnification). The wound-closure rate was calculated as described and expressed as $\%$ closure vs. relative to T0 at $18 \mathrm{~h}$ and $24 \mathrm{~h}$. Data are expressed as the mean \pm SD of one experiment in duplicate. For the comparative analysis of groups of data, repeated measures two-way ANOVA followed by a Bonferroni post hoc test were used $\left.{ }^{*} p<0.05{ }^{* *} p<0.01,{ }^{* * *} p<0.001\right)$. 


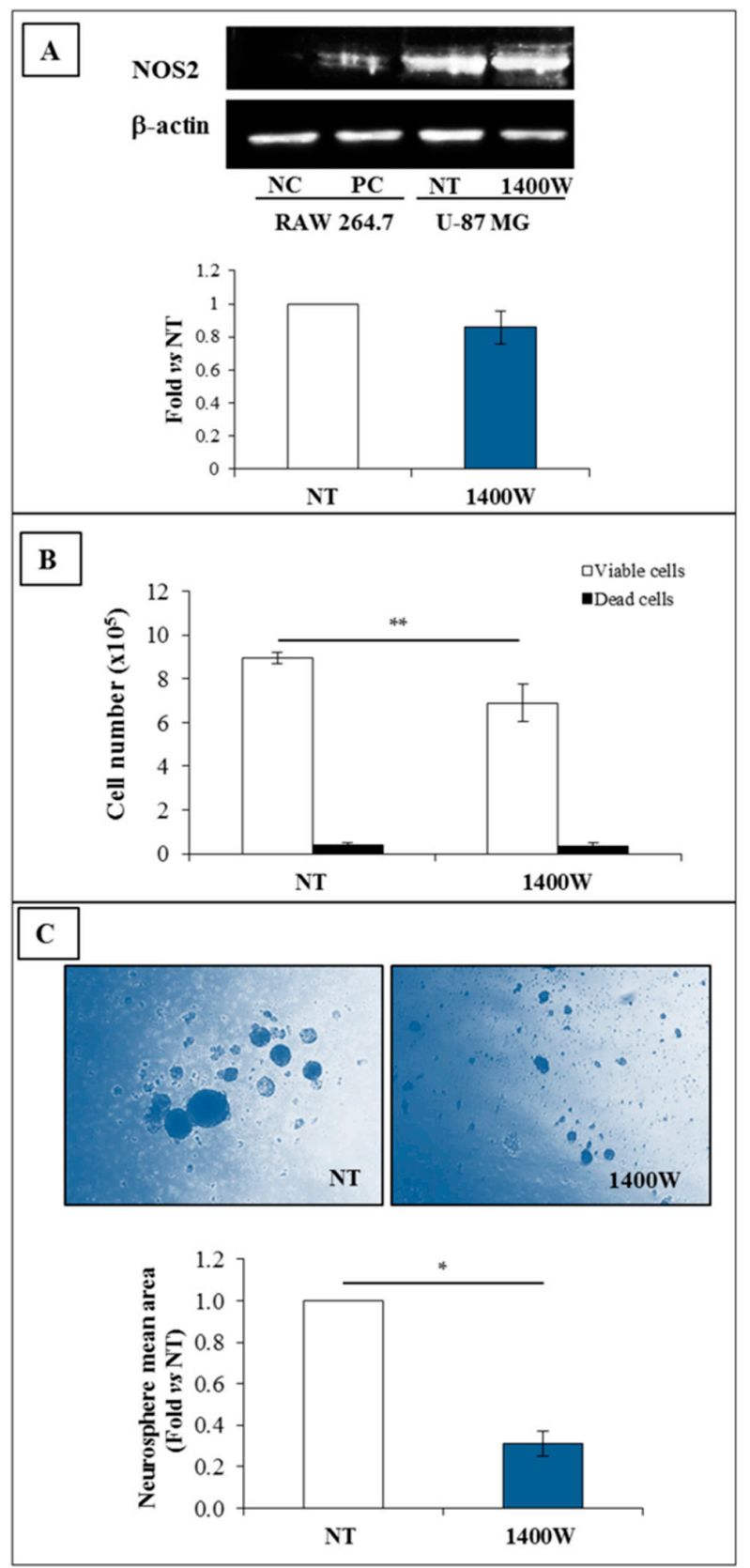

Figure 8. NOS2 expression in T98G-derived neurospheres. (A) Representative Western blot of NOS2 and $\beta$-actin of T98G-generated neurospheres not treated (NT) or treated with $1400 \mathrm{~W}(100 \mu \mathrm{M})$ which was daily added to the culture for 20 days. NC (negative control): Untreated RAW 264.7; PC (positive control): RAW 264.7 treated with LPS $(1 \mu \mathrm{g} / \mathrm{mL})$ and IFN- $\gamma(100 \mathrm{ng} / \mathrm{mL})$ for $24 \mathrm{~h}$. Results of quantification analysis of blots by densitometry, expressed as fold vs. NT, are reported in the histogram and relative to one experiment in duplicate (mean \pm SD). For comparison between NT and 1400W conditions, Student's unpaired $t$-test was used (not significant). (B) Effect of NOS2 inhibitor 1400W $(100 \mu \mathrm{M})$ on the cell number of T98G neurospheres after $24 \mathrm{~h}$ of culture. The results from one experiment in duplicate are shown as mean \pm SD. For comparison between two means, a Student's unpaired t-test was used ( $\left.{ }^{* *} p<0.01\right)$. (C) Representative phase contrast images $(4 \times$ magnification) of T98G neurospheres in the absence (NT) or presence of 1400W $(100 \mu \mathrm{M})$ added daily added for 20 days. The quantification analysis of neurosphere mean area reported as fold vs. NT is shown in the histogram and expressed as the mean \pm SD of one experiment in duplicate. For comparison between two means, Student's unpaired $t$-test was used $(* p<0.05)$. 
2.6. Involvement of NOS2 on the Clonogenic Potential and Ability to Generate Neurospheres of Glioma Primary Cells

The involvement of NOS2 activity was also investigated in the human glioma primary cells. As observed in the U-87 MG and T98G cell lines, glioma primary cells cultured in St-M basically expressed NOS2 (Figure 9A). The addition of 1400W strongly and negatively affected both the cell growth and colony formation $(p<0.05$ and $p<0.01$ versus not treated control cells, respectively) (Figure 9B,C). However, 1400W did not influence cell viability ( $>95 \%$ viable cells). NOS2 protein resulted in overexpressed neurospheres generated by the primary glioma cells after 20 days of culture in GSC-M as compared to relative adherent cells cultured in St-M. Also in this case, no effect on NOS2 protein levels was evidenced after the daily addition of 1400W for 20 days (Figure 9D). On the other hand, neurosphere generation by primary glioma cells was strongly and significantly reduced by $1400 \mathrm{~W}$ treatment, either in terms of number or size. In Figure 9E, representative images are shown captured with phase contrast microscope together data of neurosphere mean area expressed as mean \pm SEM ( $p<0.01$ as compared to NT at 20 days). 


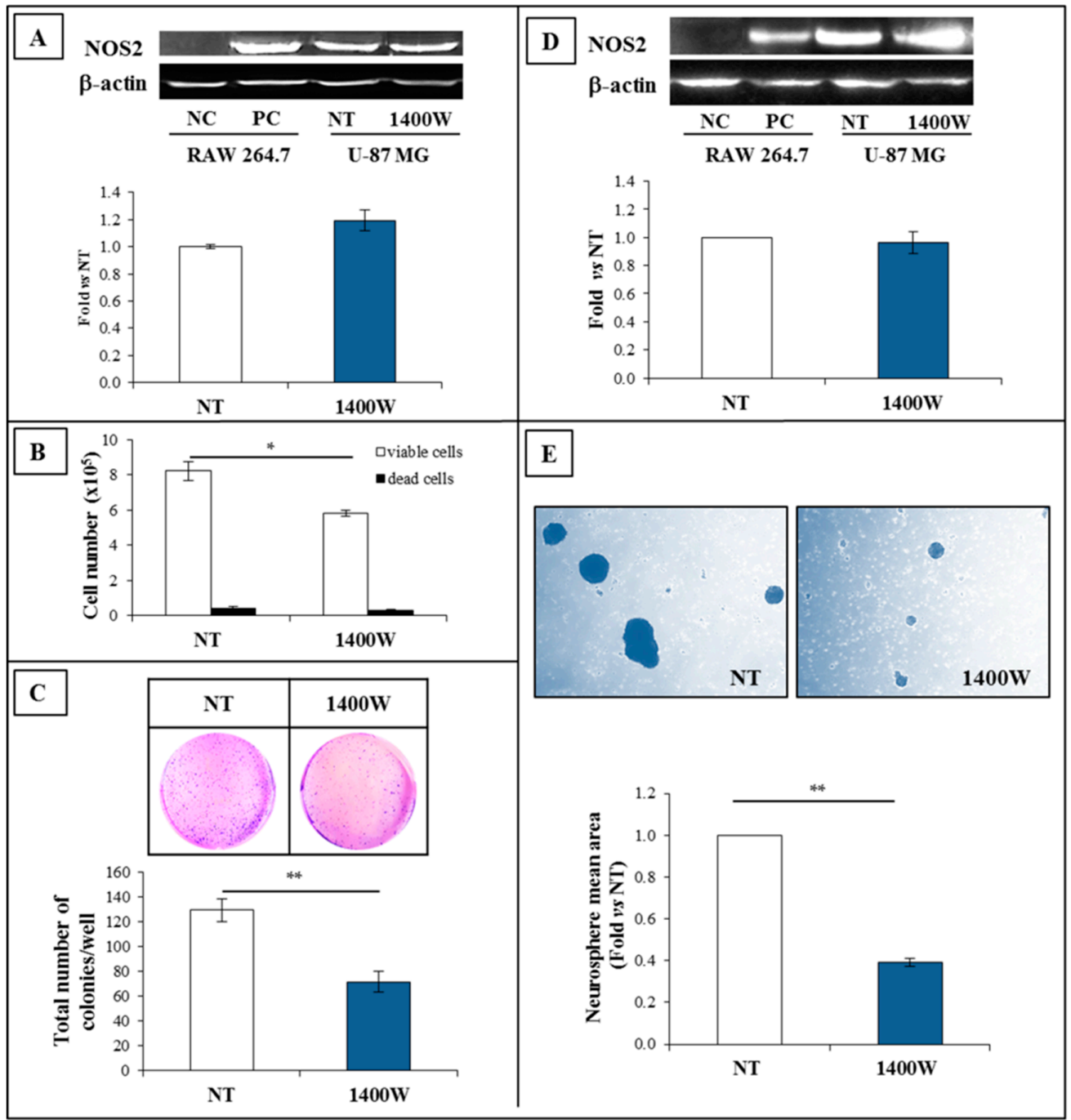

Figure 9. NOS2 expression in human glioblastoma primary cultures. (A) Representative Western blot of NOS2 and $\beta$-actin in GBM adherent glioma primary cells cultured in standard condition for 24 h. NC (negative control): Untreated RAW 264.7; PC (positive control): RAW 264.7 treated with LPS $(1 \mu \mathrm{g} / \mathrm{mL})$ and IFN- $\gamma(100 \mathrm{ng} / \mathrm{mL})$ for $24 \mathrm{~h}$. Results of quantification analysis of blots by densitometry expressed as fold vs. NT are reported in the histogram. The results from two independent experiments in duplicate are presented as mean \pm SEM. (B) Effect of NOS2 inhibitor, 1400W (100 $\mu \mathrm{M})$ on GBM adherent glioma primary culture cell number (viable and dead cells) after $24 \mathrm{~h}$ of culture. The results from two independent experiments in duplicate are presented as mean $\pm \mathrm{SEM}$. For comparison between two means, Student's unpaired $t$-test was used $\left({ }^{*} p<0.05\right)$. (C) Representative microscopic images of the clonogenic assay of human adherent GBM primary culture not treated (NT) or treated daily with NOS2 activity inhibitor $1400 \mathrm{~W}(100 \mu \mathrm{M})$ for 20 days. Quantitative results of clonogenic assay are reported in the histogram and expressed as the total number of surviving colonies/well. Data represent the mean \pm SEM of two independent experiments in duplicate. For comparison between two means, Student's unpaired t-test was used (** $p<0.01)$. (D) Representative Western blot of NOS2 and $\beta$-actin in primary culture-generated neurospheres not treated (NT) or treated with 1400W (100 $\mu \mathrm{M})$, which was daily added to the culture for 20 days. NC (negative control): Untreated RAW 264.7; PC (positive control): RAW 264.7 treated with LPS $(1 \mu \mathrm{g} / \mathrm{mL})$ and IFN- $\gamma(100 \mathrm{ng} / \mathrm{mL})$ for $24 \mathrm{~h}$. Results of quantification analysis of blots by densitometry, expressed as fold vs. NT are reported in the histogram. The results from three independent experiments are presented as mean \pm SEM. For comparison between NT and 1400W conditions, Student's unpaired $t$-test was used. (E) Representative phase contrast images (4× magnification) of human GBM primary culture maintained in GSC-M condition (GSCs) to allow neurosphere generation in the absence (not treated, NT) or presence of $1400 \mathrm{~W}(100 \mu \mathrm{M})$, added daily for 20 days. Quantification analysis of neurosphere mean area reported as fold vs. NT is shown in the histogram and expressed as the mean \pm SEM of two independent experiments in duplicate. For comparison between two means, Student's unpaired $t$-test was used $\left.{ }^{* *} p<0.01\right)$. 


\section{Discussion}

Despite advances in therapeutic approaches, the poor prognosis of patients with GBM has not improved, with a mean survival of $\sim 15$ months. Thus, new therapeutic stratagems that can successfully suppress GBM are urgently required. Actually, GSCs are mainly considered to be responsible for high resistance to therapies and tumor recurrence. NOS2 was shown to play an important role in GSC survival, proliferation, stemness expression, and therapy resistance. Fractionated radiotherapy has been reported to increase SOX2 and Notch expression through NOS2/NO system upregulation, leading to glioma resistance to radiotherapy [25]. NO signaling has been involved in the ID4 (inhibitor of differentiation-4)-induced enhancing effect on SOX2 expression and the resistance of GSC to chemotherapy $[38,39]$. NOS2 expression was shown to promote the induction of stem cell properties in GBM cells [40]. The positive regulatory circuit that is associated with platelet-derived growth factor (PDGF)-NO-ID4 signaling has been suggested to play a pivotal role in regulating the self-renewal and glioma-initiating cells (GICs) [40]. According to a recent article, the upmodulation of NOS2, among other inflammatory enzymes (i.e., COX2), is associated with cell survival mechanisms during an oxidative stress condition by which GBM cells adapted themselves to aberrant metabolic activities [41]. A crucial role of the NOS2/NO system in immunosuppression has also been evidenced [42,43]. Recently, in a model system of GBM-non-ionizing photodynamic therapy-the reported findings indicated that suppressing NOS2 expression markedly increased the efficacy of anti-tumor therapy [44]. Recently, the ability of temozolomide (TMZ), alone or in combination with thymoquinone (TQ), to reduce NO production by U-87 MG cells has been suggested as a potential mechanism underlying its anti-glioma activity $[45,46]$. The pharmacological inhibition of NOS by L-NMMA ( $\mathrm{N}^{\mathrm{G}}$-Monomethyl-L-arginine) has been reported to enhance chemotherapy response in triple negative breast cancer (TNBC) models, significantly reducing tumor volume growth and increasing the survival rate [47]. Our group has recently shown that the basal levels of NOS2/NO system expression significantly increased in the glioma cell derived-neurospheres. Similarly, also, glioma primary cell-derived neurospheres showed higher levels of NOS2 expression and activity when compared to the adherent tumor cells cultured in standard conditions [28]. SOX-2, which is a member of the SRY-related HMG-box (SOX) transcription factor family involved in several cellular processes, has been implicated in cancer development [48-50]. SOX-2 is considered a key factor in both tumorigenicity and drug resistance in GSCs. According to some authors, SOX-2 knockdown indeed strongly affects the sphere generation capacity in glioma cell cultures, the dedifferentiation rate, and the stemness phenotype, thus reducing tumorigenicity $[25,51,52]$. Of note, we recently and firstly showed a high and significant correlation between NOS2 and SOX-2 expression in glioma cells [28].Collectively, all of these studies, among others, suggest that NO signaling plays an important role in GSC maintenance and resistance to anticancer therapies. Thus, the NOS2/NO system as a biomarker for glioma and/or as a potential pharmacological target is extremely promising. In this context, the inhibition of NO production may have a significant therapeutic potential also to improve conventional treatment, even if the clinical studies are still limited [53]. A phase I open-label study was conducted to assess the combination of ASP9853, an inhibitor of NOS2 dimerization, which results in a decrease of NO production, plus docetaxel in patients with advanced solid tumors [54]. Based on the observed toxicities, the study was discontinued due to neutropenia. On the other hand, simple arginine derivatives, known as pan-NOS inhibitors (i.e., L-NMMA), were proven to be non toxic in different clinical trials as hemodynamic modulators [55]. Of note, a clinical phase $1 \mathrm{~b}$ trial of L-NMMA plus docetaxel in the treatment of refractory locally advanced or metastatic triple negative breast cancer patients is in progress, and no dose-limiting toxicities have been reported to date [56].

In an effort to highlight the functional role of the NOS2/NO system in glioma biology, the purpose of the current study was to explore the effect of the NOS2 inhibitor $1400 \mathrm{~W}$ at no cytotoxic concentrations toward the proliferation and migration rate, clonogenic potential, and neurosphere generation ability of glioma cells expressing high levels of NOS2. NOS2, which is basically expressed in the U-87 MG, T98G glioma cell lines and human glioma primary cells, was confirmed to be upmodulated in the relative 
neurospheres generated in specific culture conditions. Of note, $1400 \mathrm{~W}$, at an effective concentration to inhibit NO generation, was able to significantly reduce the proliferation, migration, colony formation, and neurosphere generation abilities of glioma cells, thus supporting the emerging relevance of NOS2 as a functional player in glioma biology. Results from experiments that aimed to investigate the effect of the NO chemical donor SNAP also support a functional role for NO in the glioma cell survival and proliferation rates as well as clonogenic potential. In addition, the methodological approaches used in this work to study proliferation and migration, together with those aimed at verifying the tumor potential of developing spheres, appear useful for the screening of new and increasingly specific NOS2 inhibitors such as acetamidines, which have been recently discovered and are structurally related to the 1400W [31]. In this context, our findings could represent a useful contribution to the development of potential therapeutic approaches for the treatment of glioma based on knowledge of the signaling pathways involved in the NO-mediated glioma cell regulation. At the same time, further studies are required to gain insights into the signaling networks involved in NOS2/NO system expression and overexpression, which in turn might underlie the abnormal expansion of GICs.

\section{Materials and Methods}

\subsection{GBM Cell Lines and Neurosphere Generation}

U-87 MG and T98G, which are both human grade IV glioma cell lines, were purchased from the European Collection of Authenticated Cell Cultures (ECACC) and American Type Culture Collection (ATCC), respectively. Allen et al. reported the origin of the U-87 MG cell line as mislabeled and unknown; they compared the original U-87MG cell line firstly identified at Uppsala University with the commercial U-87MG cell line from ATCC HTB 14TM. Genotyping analysis revealed that the ATCC and Uppsala U-87 MG cell lines were from distinct origins [57]; however, other recent studies [58-60] have demonstrated that the U-87MG ATCC cell line has several typical characteristics of glioblastoma through analyses of cell morphology and gene expression profile, even though the origin patient is unknown. Thus, U-87 MG can be used as a bonafide human glioblastoma cell line. Here, we used a U-87 MG cell line (89081402) obtained from the European Collection of Authenticated Cell Cultures (ECACC) showing a DNA profile similar to U87 (ATCC). Adherent cell lines were cultured in DMEM (Dulbecco's Modified Eagle Medium) supplemented with 10\% $(v / v)$ of fetal calf serum (FCS), $2 \mathrm{mM}$ L-glutamine, $100 \mathrm{U} / \mathrm{mL}$ penicillin, and $100 \mathrm{mg} / \mathrm{mL}$ streptomycin (standard medium, St-M) within cell culture flasks $\left(25 \mathrm{~cm}^{2}\right)$ at a density of $15 \times 10^{3} / \mathrm{cm}^{2}$ and incubated in sterile conditions at $37^{\circ} \mathrm{C}$ in a $5 \%$ $\mathrm{CO}_{2}$ humidified atmosphere. After reaching $80 \%$ confluence, adherent cell cultures were expanded after previous detachment with trypsin solution from bovine pancreas. The complete medium was totally replaced every three days. At approximately $70 \%$ confluence, the cells were treated or not with $\mathrm{N}$-(3-(aminomethyl)benzyl)acetamidine (1400W) (Sigma Chemical Co., Milan, Italy) $(100 \mu \mathrm{M}$ in PBS solution) for $24 \mathrm{~h}$. PBS at the same volume was added to the control conditions. Afterward, cell number and viability were evaluated by trypan blue dye exclusion assay $(0.04 \%$ in PBS) in a Bürker chamber by using an optical microscopy (Eclipse 50i, Nikon Corporation, Tokyo, Japan). The cell number of live and dead cells was registered. Where specified, cells were treated with an NO-donor S-nitroso- $N$-acetylpenicillamine (SNAP) (Cayman Chemical-Ann Arbor, MI, USA), as an exogenous NO source. SNAP was used at the concentration of $100 \mu \mathrm{M}$, as previously suggested [61]. Cell viability was also assessed by flow cytometric analysis, by incubating cells with propidium iodide (PI) for $30 \mathrm{~min}$; then, both viable and dead cells were analyzed using a flow cytometer (BD Instruments Inc., San José, CA, USA), and the BD CellQuest Software program (BD Instruments Inc.)

To generate neurospheres, glioma cell lineswerekept in serum-free DMEM/F12 (1:1, v/v), a specific medium for brain tumor stem cell growth, containing $20 \mathrm{ng} / \mathrm{mL}$ of both recombinant human epidermal growth factor (EGF) and basic fibroblast growth factor (b-FGF), B27 supplement, penicillin/streptomycin, and glutamine (Glioma Stem Cell Medium, GSC-M), as previously described [28]. Cell cultures were incubated within $25 \mathrm{~cm}^{2}$ cell culture flasks at $37^{\circ} \mathrm{C}$ in a humidified atmosphere with $5 \% \mathrm{CO}_{2}$, in sterile 
conditions. The obtained neurosphere cultures were routinely evaluated by flow cytometry for stemness marker expression, as yet described [8]. In all of the experiments, used neurospheres showed a high positivity for $\beta$-tubulin $(>60 \%)$, nestin $(>80 \%)$, and SOX-2 $(>60 \%)$. Neurospheres were daily treated or not with the NOS2 inhibitor $1400 \mathrm{~W}$ at $100 \mu \mathrm{M}$, as previously suggested [24]. The morphology of cell lines cultured in St-M and derived neurospheres obtained in GSC-M was visualized and imaged by Nikon Eclipse TS100 at several time intervals of the experiment. Where not otherwise specified, the reagents and consumables were purchased from EuroClone (EuroClone, West York, UK). Neurosphere size was evaluated at 20 culture days in the absence or presence of 1400W $(100 \mu \mathrm{M})$. Briefly, 10 bright field images, at $4 \times$ magnification, were randomly taken from each condition with an inverted microscope under phase contrast mode and analyzed using Image $\mathrm{J}$ software. The neurosphere average area, as expressed in $\mathrm{mm}^{2}$, was calculated dividing the entire neurosphere area by the total number of neurospheres. Each experiment was performed in duplicate.

\subsection{Glioma Primary Cell Culture and Neurosphere Generation}

Glioma primary culture was obtained from a human solid biopsy with the diagnosis of Grade IV glioma (glioblastoma multiforme, GBM) of a patient affected by malignant glioma, as confirmed by neuropathological examination, who underwent a surgical exeresis, in accordance with fluorescence-guided tumor resection protocol (ALAPDD assisted resection). The enrolled GBM patient presented with a preoperative KPS (Karnofsky Performance Status) of 80. The tumor biopsy was positive for GFAP (glial fibrillary acidic protein), positive for the proliferative marker Ki67 $(50 \%)$, and negative for IDH1 (isocitrate dehydrogenase) mutation. The study was approved by the Ethics Committee of the University of L'Aquila (n. 40070), and the patient gave written informed consent. Tumor biopsy was obtained from the Neurosurgery Unit, S. Salvatore Hospital, L'Aquila, Italy. Method for primary culture isolation was previously described [8]. Briefly, fresh surgical specimens were washed in PBS and mechanically manipulated by scalpel to remove blood cells and visible necrotic portions. To obtain single cell suspensions, mechanical and enzymatic tissue dissociation was performed by scalpel and trypsin solution at $37^{\circ} \mathrm{C}$ for $15-20 \mathrm{~min}$ in a water bath by gentle stirring. Thus, the primary culture was expanded after reaching $80 \%$ confluence and was cultured in St-M to establish adherent cultures or GSC-M to generate neurospheres. The cells were incubated in sterile conditions at $37^{\circ} \mathrm{C}$ in a $5 \% \mathrm{CO} 2$ humidified atmosphere, and medium was totally replaced every three days. Cell number and viability were determined using the trypan blue dye, as above described for the glioma cell line, and the morphology was analyzed by Nikon Eclipse TS100 microscope (Nikon, Tokyo, Japan). The morphology, size, and phenotype of primary GBM culture derived-neurospheres was evaluated as above described for U-87 MG cells.

\subsection{Western Blot}

Cell pellets were collected and homogenized in ice-cold RIPA buffer (phosphate buffer saline $\mathrm{pH} 7.4$ supplemented with $0.5 \%$ sodium deoxycolate, $1 \%$ NP40, $0.1 \%$ SDS, $5 \mathrm{mM}$ of EDTA (Ethylenediaminetetraacetic acid), $100 \mathrm{mM}$ of sodium fluoride, $2 \mathrm{mM}$ of sodium pyrophosphate, $1 \mathrm{mM}$ of PMSF (Phenylmethylsulfonyl fluoride), $2 \mathrm{mM}$ of ortovanadate, $10 \mu \mathrm{g} / \mathrm{mL}$ of leupeptin, $10 \mu \mathrm{g} / \mathrm{mL}$ of aprotinin, $10 \mu \mathrm{g} / \mathrm{mL}$ of pepstatin). Homogenates were centrifuged at $600 \times \mathrm{g}$ for $30 \mathrm{~min}$ at $4{ }^{\circ} \mathrm{C}$, and the protein content was quantified into supernatants using the BCA protein assay kit (Pierce, Rockford, IL, USA). Samples (40 $\mathrm{\mu g}$ /lane) were run on $8.5 \%$ SDS polyacrylamide gels according to standard procedures, and proteins were transferred onto nitrocellulose membranes. Non-specific binding sites were blocked with $5 \%$ non-fat dry milk for $1 \mathrm{~h}$ at room temperature, and membranes were incubated overnight at $4{ }^{\circ} \mathrm{C}$ with primary antibody anti-NOS2 (Thermo Fisher Scientific, Waltham, Massachusetts, United States), and anti- $\beta$-actin (Bio-Rad, Hercules, CA, USA). Secondary antibodies, anti-rabbit IgG for NOS2 detection and anti-rabbit IgG for $\beta$-actin, were used, and immunoreactive bands were visualized by ECL chemiluminescent substrate reagent according to the manufacturer instructions and acquired by UVItec Alliance (Cambridge, UK). Densitometric analysis was performed 
by software provided by the company. Relative band intensity was normalized to respective $\beta$-actin bands. The murine macrophage cell line RAW 264.7 untreated or treated with LPS $(1 \mu \mathrm{g} / \mathrm{mL})$ and IFN- $\gamma(100 \mathrm{ng} / \mathrm{mL})$ for $24 \mathrm{~h}$ was used as the NOS2 negative and positive control, respectively.

\subsection{Nitrite Level Assay}

The enzymatic activity of NOS2 was evaluated by measuring nitrite levels using nitrate reductase and Griess reaction through a colorimetric assay (Nitrite Assay kit-Sigma-Aldrich Co., Milan, Italy). Glioma cells and relative-derived neurospheres were seeded as above described for different incubation times, after which nitrite levels were assayed in the cell supernatants applied to a 96-well microtiter plate, according to the manufacturer's instructions. The absorbance was measured by spectrophotometric reading at $550 \mathrm{~nm}$ using a microplate reader (Bio-Rad, Hercules, CA, USA). The nitrite content of each sample was evaluated with a standard curve obtained by linear regression made with sodium nitrite and expressed in $\mu \mathrm{g} / \mathrm{mL}$. Each sample was assayed in duplicate.

\subsection{Clonogenic Assay}

The ability of the glioma cells to generate in vitro colonies was determined using clonogenic assay. Briefly, U-87 MG, T98G, and glioma primary cells were incubated in St-M in six-well plates at a concentration of 1.000 cells/well until colony formation. The medium was regularly changed. The cells were daily treated with $1400 \mathrm{~W}(100 \mu \mathrm{M})$ or SNAP $(100 \mu \mathrm{M})$. After 10 days for U-87 MG and T98G, and 15 days for glioma primary cells, the supernatants were removed; then, colonies were gently washed with PBS, fixed with cold methanol for $20 \mathrm{~min}$, and stained with crystal violet $0.1 \%$ in PBS at room temperature for $10 \mathrm{~min}$ and air-dried. Images were captured and the total number of colonies/well was counted.

\subsection{Cell Migration Assays}

The effect of $1400 \mathrm{~W}$ on glioma cell proliferation and migration was assessed using wound-healing assay, as previously described [62]. U-87 MG and T98G cells were plated at $6 \times 10^{4} / \mathrm{cm}^{2}$ in six-well plates and cultured until reaching confluence. DMEM was removed and cell monolayers were scratched using a $200-\mu \mathrm{L}$ pipet tip. Then, the cells were washed with PBS in order to remove debris, and cultures were incubated with fresh medium at $37^{\circ} \mathrm{C}$ in a $5 \% \mathrm{CO} 2$ humidified atmosphere in the absence or presence of $1400 \mathrm{~W}(100 \mu \mathrm{M})$ or the NO chemical donor SNAP $(100 \mu \mathrm{M})$. Images of cell migration were captured by an inverted light microscope (Eclipse TS 100, Nikon) (10× magnification) at different time points after the injury $(0-36 \mathrm{~h})$. The experiments were conducted in duplicate, and nine fields for each condition were analyzed. To calculate the percentage of wound closure, the images were analyzed quantitatively using the standalone TScratch software that automatically calculates the portion of area occupied by the cells by a mathematical model [63]. The quantification of a relative scratched monolayer closure (wound closure) was performed according to the equation where $\mathrm{Tn}$ is a specific time point after the scratching:

$\%$ Relative wound closure $=\underline{[\% \text { of scratched area at T0- } \% \text { of scratched area at Tn }](\times 100)}$ [\% of scratched area at $\mathrm{T} 0]$

\subsection{Statistical Analysis}

All of the data were analyzed using Prism 6.0 GraphPad Software (GraphPad, San Diego, CA, USA). Results are expressed as mean \pm SEM from two or three independent experiments conducted in duplicate or triplicate, as specified. The results of the T98G cell line are presented as the mean $\pm \mathrm{SD}$ of one experiment performed in duplicate. For comparison between two means, Student's unpaired $t$-test was used. For comparisons of the mean values among groups, a one-way or repeated measures two-way ANOVA followed by Bonferroni post hoc test were used. Values of $p$ less than 0.05 were accepted as significant. 
Author Contributions: Conceptualization, P.P., F.L., M.G.C., B.C.; Data curation, P.P., F.L.; Funding acquisition, M.G.C.; Investigation, P.P., F.L., G.S., S.R.D., S.L.; Methodology, P.P., F.L., G.S., S.R.D., S.L.; Project administration, M.G.C., B.C.; Supervision, M.G.C., B.C.; Writing—original draft, P.P., F.L.; Writing—review \& editing, A.C., M.G.C., B.C.

Funding: This research was funded by Department of Life, Health \& Environmental Sciences, University of L'Aquila grant number RIA MCM 2017.

Acknowledgments: The study has been performed in the framework of the "Research Center for Molecular Diagnostics and Advanced Therapies" supported by the "Abruzzo earthquake relief fund" (Toronto, Ontario). The Authors thank Gasperina De Nuntiis (Department of Life, Health \& Environmental Sciences, University of L'Aquila, L'Aquila, Italy) for excellent technical assistance.

Conflicts of Interest: The authors declare no conflict of interest.

\section{Abbreviations}

$\begin{array}{ll}\text { GBM } & \text { Glioblastoma multiforme } \\ \text { GSCs } & \text { Glioma Stem Cells } \\ \text { GICs } & \text { Glioma Initiating Cells } \\ \text { NOS2 } & \text { Nitric Oxide Synthase 2 } \\ \text { NO } & \text { Nitric Oxide } \\ \text { 1400W } & \text { N-(3-(Aminomethyl)benzyl)acetamidine } \\ \text { SNAP } & \text { S-nitroso-N-acetylpenicillamine } \\ \text { St-M } & \text { Standard Medium } \\ \text { GSC-M } & \text { Glioma Stem Cell Medium } \\ \text { KPS } & \text { Karnofsky Performance Status } \\ \text { GFAP } & \text { Glial fibrillary acidic protein } \\ \text { IDH1 } & \text { Isocitrate dehydrogenase 1 } \\ \text { TMZ } & \text { Temozolomide } \\ \text { L-NMMA } & N^{G} \text {-Monomethyl-L-arginine }\end{array}$

\section{References}

1. Chen, R.; Cohen, A.L.; Colman, H. Targeted therapeutics in patients with high-grade gliomas: Past, present, and future. Curr. Treat. Opt. Oncol. 2016, 17, 42. [CrossRef] [PubMed]

2. Perry, A.; Wesseling, P. Histologic classification of gliomas. Handb. Clin. Neurol. 2016, 134, 71-95. [CrossRef] [PubMed]

3. Wesseling, P.; Jacques, T.S. Taxonomy of CNS tumours; a series of three short reviews on the WHO 2016 classification and beyond. Neuropathol. Appl. Neurobiol. 2018, 44, 137-138. [CrossRef] [PubMed]

4. Gusyatiner, O.; Hegi, M.E. Glioma epigenetics: From subclassification to novel treatment options. Semin. Cancer Biol. 2017, 10445. [CrossRef] [PubMed]

5. Barthel, F.P.; Wesseling, P.; Verhaak, R.G.W. Reconstructing the molecular life history of gliomas. Acta Neuropathol. 2018, 135, 649-670. [CrossRef] [PubMed]

6. Zhang, X.; Zhang, W.; Mao, X.G.; Zhen, H.N.; Cao, W.D.; Hu, S.J. Targeting role of glioma stem cells for glioblastoma multiforme. Curr. Med. Chem. 2013, 20, 1974-1984. [CrossRef] [PubMed]

7. Binda, E.; Reynolds, B.A.; Vescovi, A.L. Glioma stem cells: Turpis omen in nomen? (The evil in the name?). J. Int. Med. 2014, 276, 25-40. [CrossRef] [PubMed]

8. Miconi, G.; Palumbo, P.; Dehcordi, S.R.; La Torre, C.; Lombardi, F.; Evtoski, Z.; Cimini, A.M.; Galzio, R.; Cifone, M.G.; Cinque, B. Immunophenotypic Characterization of Human Glioblastoma Stem Cells: Correlation with Clinical Outcome. J. Cell Biochem. 2015, 116, 864-876. [CrossRef] [PubMed]

9. Fidoamore, A.; Cristiano, L.; Antonosante, A.; d'Angelo, M.; Di Giacomo, E.; Astarita, C.; Giordano, A.; Ippoliti, R.; Benedetti, E.; Cimini, A. Glioblastoma Stem Cells Microenvironment: The Paracrine Roles of the Niche in Drug and Radioresistance. Stem Cells Int. 2016, 2016, 6809105. [CrossRef] [PubMed]

10. Roos, A.; Ding, Z.; Loftus, J.C.; Tran, N.L. Molecular and Microenvironmental Determinants of Glioma Stem-Like Cell Survival and Invasion. Front. Oncol. 2017, 7, 120. [CrossRef] [PubMed]

11. Lau, E.Y.T.; Ho, N.P.Y.; Lee, T.K.W. Cancer Stem Cells and Their Microenvironment: Biology and Therapeutic Implications. Stem Cells Int. 2017, 2017, 3714190. [CrossRef] [PubMed] 
12. Bien-Moller, S.; Balz, E.; Herzog, S.; Plantera, L.; Vogelgesang, S.; Weitmann, K.; Seifert, C.; Fink, M.A.; Marx, S.; Bialke, A.; et al. Association of Glioblastoma Multiforme Stem Cell Characteristics, Differentiation, and Microglia Marker Genes with Patient Survival. Stem Cells Int. 2018, 17, 9628289. [CrossRef] [PubMed]

13. Hira, V.V.V.; Aderetti, D.A.; van Noorden, C.J.F. Glioma stem cell niches in human glioblastoma are periarteriolar. J. Histochem. Cytochem. 2018, 66, 349-358. [CrossRef] [PubMed]

14. Grivennikov, S.I.; Greten, F.R.; Karin, M. Immunity, Inflammation, and Cancer. Cell 2010, 140, $883-899$. [CrossRef] [PubMed]

15. Diakos, C.I.; Charles, K.A.; McMillan, D.C.; Clarke, S.J. Cancer related inflammation and treatment effectiveness. Lancet Oncol. 2014, 15, E493-E503. [CrossRef]

16. Shalapour, S.; Karin, M. Immunity, inflammation, and cancer: An eternal fight between good and evil. J. Clin. Investig. 2015, 125, 3347-3355. [CrossRef] [PubMed]

17. Salazar-Ramiro, A.; Ramirez-Ortega, D.; de la Cruz, V.P.; Hernandez-Pedro, N.Y.; Gonzalez-Esquivel, D.F.; Sotelo, J.; Pineda, B. Role of Redox Status in Development of Glioblastoma. Front. Immunol. 2016, 7, 156. [CrossRef] [PubMed]

18. Domenis, R.; Cesselli, D.; Toffoletto, B.; Bourkoula, E.; Caponnetto, F.; Manini, I.; Beltrami, A.P.; Ius, T.; Skrap, M.; Di Loreto, C.; et al. Systemic T Cells Immunosuppression of Glioma Stem Cell-Derived Exosomes Is Mediated by Monocytic Myeloid-Derived Suppressor Cells. PLoS ONE 2017, 12, e0169932. [CrossRef] [PubMed]

19. Qu, X.; Tang, Y.; Hua, S. Immunological Approaches Towards Cancer and inflammation: A Cross Talk. Front. Immunol. 2018, 20, 563. [CrossRef] [PubMed]

20. Jahani-Asl, A.; Bonni, A. iNOS: A Potential Therapeutic Target for Malignant Glioma. Curr. Mol. Med. 2013, 13, 1241-1249. [CrossRef] [PubMed]

21. Bogdan, C. Nitric oxide synthase in innate and adaptive immunity: An update. Trends Immunol. 2015, 36, 161-178. [CrossRef] [PubMed]

22. Vannini, F.; Kashfi, K.; Nath, N. The dual role of iNOS in cancer. Redox Biol. 2015, 6, 334-343. [CrossRef] [PubMed]

23. Tran, A.N.; Boyd, N.H.; Walker, K.; Hjelmeland, A.B. NOS Expression and NO Function in Glioma and Implications for Patient Therapies. Antioxid. Redox Signal. 2017, 26, 986-999. [CrossRef] [PubMed]

24. Eyler, C.E.; Wu, Q.L.; Yan, K.; MacSwords, J.M.; Chandler-Militello, D.; Misuraca, K.L.; Lathia, J.D.; Forrester, M.T.; Lee, J.; Stamler, J.S.; et al. Glioma Stem Cell Proliferation and Tumor Growth Are Promoted by Nitric Oxide Synthase-2. Cell 2011, 146, 53-66. [CrossRef] [PubMed]

25. Kim, R.K.; Suh, Y.; Cui, Y.H.; Hwang, E.; Lim, E.J.; Yoo, K.C.; Lee, G.H.; Yi, J.M.; Kang, S.G.; Lee, S.J. Fractionated radiation induced nitric oxide promotes expansion of glioma stem like cells. Cancer Sci. 2013, 104, 1172-1177. [CrossRef] [PubMed]

26. Shen, S.C.; Wu, M.S.; Lin, H.Y.; Yang, L.Y.; Chen, Y.H.; Chen, Y.C. Reactive oxygen species-dependent nitric oxide production in reciprocal interactions of glioma and microglial cells. J. Cell Physiol. 2014, 229, 2015-2026. [CrossRef] [PubMed]

27. Papaevangelou, E.; Whitley, G.S.; Johnstone, A.P.; Robinson, S.P.; Howe, F.A. Investigating the role of tumour cell derived iNOS on tumour growth and vasculature in vivo using a tetracycline regulated expression system. Int. J. Cancer 2016, 138, 2678-2687. [CrossRef] [PubMed]

28. Palumbo, P.; Miconi, G.; Cinque, B.; Lombardi, F.; La Torre, C.; Dehcordi, S.R.; Galzio, R.; Cimini, A.; Giordano, A.; Cifone, M.G. NOS2 expression in glioma cell lines and glioma primary cell cultures: Correlation with neurosphere generation and SOX-2 expression. Oncotarget 2017, 8, 25582-25598. [CrossRef] [PubMed]

29. Re, N.; Fantacuzzi, M.; Maccallini, C.; Paciotti, R.; Amoroso, R. Recent developments of amidine-like compounds as selective NOS inhibitors. Curr. Enzyme Inhib. 2016, 12, 30-39. [CrossRef]

30. Fedorov, R.; Hartmann, E.; Ghosh, D.K.; Schlichting, I. Structural basis for the specificity of the nitric-oxide synthase inhibitors W1400 and Nu-propyl-L-argfor the inducible and neuronal isoforms. J. Biol. Chem. 2003, 278, 45818-45825. [CrossRef] [PubMed]

31. Maccallini, C.; Di Matteo, M.; Gallorini, M.; Montagnani, M.; Graziani, V.; Ammazzalorso, A.; Amoia, P.; De Filippis, B.; Di Silvestre, S.; Fantacuzzi, M.; et al. Discovery of $N-\{3-[($ ethanimidoylamino)methyl]benzyl\}L-prolinamide dihydrochloride: A new potent and selective inhibitor of the inducible nitric oxide synthase as a promising agent for the therapy of malignant glioma. Eur. J. Med. Chem. 2018, 152, 53-64. [CrossRef] [PubMed] 
32. Garvey, E.P.; Oplinger, J.A.; Furfine, E.S.; Kiff, R.J.; Laszlo, F.; Whittle, B.J.R.; Knowles, R.G. $1400 W$ is a slow, tight binding, and highly selective inhibitor of inducible nitric-oxide synthase in vitro and in vivo. J. Biol. Chem. 1997, 272, 4959-4963. [CrossRef] [PubMed]

33. Patel, P.; Qi, W.N.; Allen, D.M.; Chen, L.E.; Seaber, A.V.; Stamler, J.S.; Urbaniak, J.R. Inhibition of iNOS with $1400 \mathrm{~W}$ improves contractile function and alters nos gene and protein expression in reperfused skeletal muscle. Microsurgery 2004, 24, 324-331. [CrossRef] [PubMed]

34. Maccallini, C.; Patruno, A.; Besker, N.; Ali, J.I.; Ammazzalorso, A.; De Filippis, B.; Franceschelli, S.; Giampietro, L.; Pesce, M.; Reale, M.; et al. Synthesis, biological evaluation, and docking studies of $\mathrm{N}$-substituted acetamidines as selective inhibitors of inducible nitric oxide synthase. J. Med. Chem. 2009, 52, 1481-1485. [CrossRef] [PubMed]

35. Maccallini, C.; Patruno, A.; Lannutti, F.; Ammazzalorso, A.; De Filippis, B.; Fantacuzzi, M.; Franceschelli, S.; Giampietro, L.; Masella, S.; Felaco, M.; et al. N-Substituted acetamidines and 2-methylimidazole derivatives as selective inhibitors of neuronal nitric oxide synthase. Bioorg. Med. Chem. Lett. 2010, 20, 6495-6499. [CrossRef] [PubMed]

36. Fantacuzzi, M.; Maccallini, C.; Lannutti, F.; Patruno, A.; Masella, S.; Pesce, M.; Speranza, L.; Ammazzalorso, A.; De Filippis, B.; Giampietro, L.; et al. Selective inhibition of iNOS by benzyl- and dibenzyl derivatives of $\mathrm{N}$-(3-aminobenzyl)acetamidine. Chem. Med. Chem. 2011, 6, 1203-1206. [CrossRef] [PubMed]

37. Maccallini, C.; Montagnani, M.; Paciotti, R.; Ammazzalorso, A.; De Filippis, B.; Di Matteo, M.; Di Silvestre, S.; Fantacuzzi, M.; Giampietro, L.; Potenza, M.A.; et al. Selective acetamidine-based nitric oxide synthase inhibitors: Synthesis, docking, and biological studies. ACS Med. Chem. Lett. 2015, 6, 635-640. [CrossRef] [PubMed]

38. Jeon, H.M.; Sohn, Y.W.; Oh, S.Y.; Kim, S.H.; Beck, S.; Kim, S.; Kim, H. ID4 imparts chemoresistance and cancer stemness to glioma cells by derepressing miR-9*-mediated suppression of SOX2. Cancer Res. 2011, 71, 3410-3421. [CrossRef] [PubMed]

39. Jeon, H.M.; Kim, S.H.; Jin, X.; Park, J.B.; Kim, S.H.; Joshi, K.; Nakano, I.; Kim, H. Crosstalk between glioma-initiating cells and endothelial cells drives tumor progression. Cancer Res. 2014, 74, 4482-4492. [CrossRef] [PubMed]

40. Eun, K.; Jeon, H.M.; Kim, S.O.; Choi, S.H.; Lee, S.Y.; Jin, X.; Kim, S.C.; Kim, H. A cell-autonomous positive-signaling circuit associated with the PDGF-NO-ID4-regulatory axis in glioblastoma cells. Biochem. Biophys. Res. Commun. 2017, 486, 564-570. [CrossRef] [PubMed]

41. Cholia, R.P.; Kumari, S.; Kumar, S.; Kaur, M.; Kaur, M.; Kumar, R.; Dhiman, M.; Mantha, A.K. An in vitro study ascertaining the role of $\mathrm{H}_{2} \mathrm{O}_{2}$ and glucose oxidase in modulation of antioxidant potential and cancer cell survival mechanisms in glioblastoma U-87 MG cells. Metab. Brain Dis. 2017, 32, 1705-1716. [CrossRef] [PubMed]

42. Birben, E.; Sahiner, U.M.; Sackesen, C.; Erzurum, S.; Kalayci, O. Oxidative stress and antioxidant defense. World Allergy Organ. J. 2012, 5, 9-19. [CrossRef] [PubMed]

43. Fionda, C.; Abruzzese, M.P.; Santoni, A.; Cippitelli, M. Immunoregulatory and Effector Activities of Nitric Oxide and Reactive Nitrogen Species in Cancer. Curr. Med. Chem. 2016, 23, 2618-2636. [CrossRef] [PubMed]

44. Fahey, J.M.; Emmer, J.V.; Korytowski, W.; Hogg, N.; Girotti, A.W. Antagonistic Effects of Endogenous Nitric Oxide in a Glioblastoma Photodynamic Therapy Model. Photochem. Photobiol. 2016, 92, 842-853. [CrossRef] [PubMed]

45. Pazhouhi, M.; Sariri, R.; Rabzia, A.; Khazaei, M. Thymoquinone synergistically potentiates temozolomide cytotoxicity through the inhibition of autophagy in U87MG cell line. Iran. J. Basic Med. Sci. 2016, 19, 890-898. [PubMed]

46. Khazaei, M.; Pazhouhi, M. Temozolomide-mediated apoptotic death is improved by thymoquinone in U87MG cell line. Cancer Investig. 2017, 35, 225-236. [CrossRef] [PubMed]

47. Dávila-González, D.; Choi, D.S.; Rosato, R.R.; Granados-Principal, S.M.; Kuhn, J.G.; Li, W.F.; Qian, W.; Chen, W.; Kozielski, A.J.; Wong, H.; et al. Pharmacological Inhibition of NOS Activates ASK1/JNK Pathway Augmenting Docetaxel-Mediated Apoptosis in Triple-Negative Breast Cancer. Clin Cancer Res. 2018, 24, 1152-1162. [CrossRef] [PubMed]

48. Zhang, S.; Cui, W. Sox2, a key factor in the regulation of pluripotency and neural differentiation. World J. Stem Cells. 2014, 26, 305-311. [CrossRef] [PubMed] 
49. Garros-Regulez, L.; Garcia, I.; Carrasco-Garcia, E.; Lantero, A.; Aldaz, P.; Moreno-Cugnon, L.; Arrizabalaga, O.; Undabeitia, J.; Torres-Bayona, S.; Villanua, J.; et al. Targeting SOX2 as a Therapeutic Strategy in Glioblastoma. Front Oncol. 2016, 6, 222. [CrossRef] [PubMed]

50. Singh, D.K.; Kollipara, R.K.; Vemireddy, V.; Yang, X.L.; Sun, Y.; Regmi, N.; Klingler, S.; Hatanpaa, K.J.; Raisanen, J.; Cho, S.K.; et al. Oncogenes Activate an Autonomous Transcriptional Regulatory Circuit That Drives Glioblastoma. Cell Rep. 2017, 18, 961-976. [CrossRef] [PubMed]

51. Kamachi, Y.; Kondoh, H. Sox proteins: Regulators of cell fate specification and differentiation. Development. 2013, 20, 4129-4144. [CrossRef] [PubMed]

52. Jung, T.Y.; Choi, Y.D.; Kim, Y.H.; Lee, J.J.; Kim, H.S.; Kim, J.S.; Kim, S.K.; Jung, S.; Cho, D. Immunological characterization of glioblastoma cells for immunotherapy. Anticancer Res. 2013, 33, 2525-2533. [PubMed]

53. Davila-Gonzalez, D.; Chang, J.C.; Billiar, TR. NO and COX2: Dual targeting for aggressive cancers. Proc. Natl. Acad. Sci. USA 2017, 52, 13591-13593. [CrossRef] [PubMed]

54. Luke, J.J.; LoRusso, P.; Shapiro, G.I.; Krivoshik, A.; Schuster, R.; Yamazaki, T.; Arai, Y.; Fakhoury, A.; Dmuchowski, C.; Infante, J.R. ASP9853, an inhibitor of inducible nitric oxide synthase dimerization, in combination with docetaxel: Preclinical investigation and a Phase I study in advanced solid tumors. Cancer Chemother. Pharmacol. 2016, 77, 549-558. [CrossRef] [PubMed]

55. Víteček, J.; Lojek, A.; Valacchi, G.; Kubala, L. Arginine-based inhibitors of nitric oxide synthase: Therapeutic potential and challenges. Mediat. Inflamm. 2012, 318087. [CrossRef]

56. Chang, J.; Rodriguez, A.; Ensor, J. Clinical phase Ib trial of L-NMMA plus docetaxel in the treatment of refractory locally advanced or metastatic triple negative breast cancer patients. In Proceedings of the American Association for Cancer Research Annual Meeting, Washington, DC, USA, 1-5 April 2017.

57. Allen, M.; Bjerke, M.; Edlund, H.; Nelander, S.; Westermark, B. Origin of the U-87 MG glioma cell line: Good news and bad news. Sci. Transl. Med. 2016, 8, 354. [CrossRef]

58. Gao, L.; Chen, B.; Li, J.; Yang, F.; Cen, X.; Liao, Z.; Long, X. Wnt/ $\beta$-catenin signaling pathway inhibits the proliferation and apoptosis of U87 glioma cells via different mechanisms. PLoS ONE 2017, 12, e0181346. [CrossRef] [PubMed]

59. Jia, W.; Jiang, X.; Liu, W.; Wang, L.; Zhu, B.; Zhu, H.; Liu, X.; Zhong, M.; Xie, D.; Huang, W.; et al. Effects of three-dimensional collagen scaffolds on the expression profiles and biological functions of glioma cells. Int. J. Oncol. 2018. [CrossRef] [PubMed]

60. Chu, C.W.; Yang, M.C.; Chou, C.H.; Huang, W.S.; Hsiao, B.X.; Wang, Y.T.; Chiou, S.J.; Loh, J.K.; Hong, Y.R. GSK3 $\beta$-mediated Ser156 phosphorylation modulates a BH3-like domain in BCL2L12 during TMZ-induced apoptosis and autophagy in glioma cells. Int. J. Mol. Med. 2018, 42, 905-918. [CrossRef] [PubMed]

61. Kurimoto, M.; Endo, S.; Hirashima, Y.; Hamada, H.; Ogiichi, T.; Takaku, A. Growth inhibition and radiosensitization of cultured glioma cells by nitric oxide generating agents. J. Neurooncol. 1999, 42, 35-44. [CrossRef] [PubMed]

62. La Torre, C.; Cinque, B.; Lombardi, F.; Miconi, G.; Palumbo, P.; Evtoski, Z.; Placidi, G.; Fanini, D.; Cimini, A.M.; Benedetti, E.; et al. Nitric Oxide Chemical Donor Affects the Early Phases of In Vitro Wound Healing Process. J. Cell Physiol. 2016, 231, 2185-2195. [CrossRef] [PubMed]

63. Gebäck, T.; Schulz, M.M.; Koumoutsakos, P.; Detmar, M. TScratch: A novel and simple software tool for automated analysis of monolayer wound healing assays. Biotechniques 2009, 46, 265-274. [CrossRef] [PubMed]

(C) 2018 by the authors. Licensee MDPI, Basel, Switzerland. This article is an open access article distributed under the terms and conditions of the Creative Commons Attribution (CC BY) license (http:/ / creativecommons.org/licenses/by/4.0/). 